\title{
Preparation and Characterization of Chromium Doped Ni-Cu-Zn Nano Ferrites
}

\author{
Bajarang Laxman Shinde, ${ }^{1}$ Laxman Appa Dhale, ${ }^{2}$ Venkat S. Suryavanshi ${ }^{3}$ \\ and Kishan Shankarrao Lohar ${ }^{2}$ \\ ${ }^{1}$ Department of Chemistry, Waghire College, Saswad Dist: Pune, 412301 (M.S.) India \\ ${ }^{2}$ Department of Chemistry, Shrikrishna Mahavidyalaya, Gunjoti, 413606, Dist: Osmanabad (M.S.) India \\ ${ }^{3}$ Department of Chemistry, Shri Chatrapati Shivaji College, Omerga, Dist: Osmanabad 413613 (M.S.) India \\ *Corresponding author: E-mail: kslohar@rediffmail.com
}

Received: 07-06-2017

\begin{abstract}
Chromium doped Ni-Cu-Zn nano ferrites with chemical formula $\mathrm{Ni}_{02} \mathrm{Cu}_{02} \mathrm{Zn}_{06} \mathrm{Fe}_{2-\mathrm{x}} \mathrm{Cr}_{\mathrm{x}} \mathrm{O}_{4}(\mathrm{x}=0.0,0.2,0.4,0.6,0.8$, and 1.0) were prepared by using sol-gel auto combustion method. The prepared precursors of Chromium substituted $\mathrm{Ni}-\mathrm{Cu}$ $\mathrm{Zn}$ ferrites were sintered at $500^{\circ} \mathrm{C}$ for $4 \mathrm{~h}$. Compositional stoichiometry were confirmed from EDAX patterns. The XRD data revealed that the all samples possess a single phase cubic spinel structure. The Lattice constant, X-ray density, hopping lengths and crystallite size determined from XRD data decreases with increase in $\mathrm{Cr}^{3+}$ concentration. The IR spectra show two major absorption bands, high frequency band $v_{1} \approx 600 \mathrm{~cm}^{-1}$ and low frequency band $v_{2} \approx 450 \mathrm{~cm}^{-1}$ attributed to the stretching vibration of tetrahedral and octahedral sites respectively. The surface morphology of the prepared samples was studied by Scanning Electron Microscopy and Transmission Electron Morphology.
\end{abstract}

Keywords: Spinel ferrite, Sol-gel auto-combustion; Thermal analysis, Morphology, X-ray diffraction

\section{Introduction}

Nano ferro spinels are of great interest for addressing relationship between physical properties and their crystal structure. Due to their reduced sizes, these nanoparticles may possess novel and/or improved properties in comparison to the bulk materials. This has renewed interest to study different properties of pure and mixed spinel ferrite systems in nanocrystalline regime. Transition metal ferrites both doped and undoped are attractive candidates for a wide range of applications including catalysis, ${ }^{1-4}$ and several devices such as antennas, permanent magnets, memory storage devices, microwave devices, telecommunication, computer etc. ${ }^{5}$ The polycrystalline ferrites such as $\mathrm{Ni}-\mathrm{Cu}-\mathrm{Zn}$ ferrites have very important structural properties dependent on several factors such as method of preparation, substitution of cations, sintering temperature, sintering time, sintering atmosphere, porosity and microstructure. ${ }^{6,7} \mathrm{Ni}-\mathrm{Cu}-\mathrm{Zn}$ ferrites were considered as one of the most versatile magnetic materials to manufacture Multilayer chip inductors (MLCIs) mainly because of their high electrical resistivity, low sintering temperature and high permeability. ${ }^{8,9}$ Recently due to better magnetic properties, controlled shape of nanocrystalline $\mathrm{Ni}-\mathrm{Cu}-\mathrm{Zn}$ ferrites have been the dominant materials for MLIC at high frequency and low sintering temperature. ${ }^{10-16}$ These oxides can be sintered at relatively low temperatures with a wide range of compositions. Recently, several methods were used to synthesize highly crystalline and uniformly sized magnetic nanoparticles of $\mathrm{Ni}-\mathrm{Cu}-\mathrm{Zn}$ ferrite. ${ }^{17-21}$ Among these methods, the sol-gel method has gained scientific and technological importance during the last three decades. ${ }^{22-25}$ The sol-gel auto-combustion synthesis method have many advantages as compared to the conventional methods such as low temperature processing and/or better homogeneity for the synthesis of multi-component materials. Considering the importance of $\mathrm{Ni}-\mathrm{Cu}-\mathrm{Zn}$ ferrite, we investigated the preparation of chromium doped $\mathrm{Ni}-\mathrm{Cu}-\mathrm{Zn}$ nano ferrite by sol-gel auto-combustion method using citric acid as fuel at low temperature with a view to study the influence of the substitution of $\mathrm{Cr}^{3+}$ ion on the structural properties of the system. 


\section{Experimental}

\section{1. Materials and Synthetic Procedure}

Nanocrystalline chromium substituted $\mathrm{Ni}-\mathrm{Cu}-\mathrm{Zn}$ ferrites, with composition $\mathrm{Ni}_{0.2} \mathrm{Cu}_{0.2} \mathrm{Zn}_{0.6} \mathrm{Fe}_{2-\mathrm{x}} \mathrm{Cr}_{\mathrm{x}} \mathrm{O}_{4}$ ( $\mathrm{x}=0.0$, $0.2,0.4,0.6,0.8$ and 1.0) were synthesized by the sol-gel auto-combustion method. Analytical reagent grade nickel nitrate $\left(\mathrm{Ni}\left(\mathrm{NO}_{3}\right)_{2} \cdot 6 \mathrm{H}_{2} \mathrm{O}\right)$, copper nitrate $\left(\mathrm{Cu}\left(\mathrm{NO}_{3}\right) \cdot 6 \mathrm{H}_{2} \mathrm{O}\right)$, zinc nitrate $\left(\mathrm{Zn}\left(\mathrm{NO}_{3}\right)_{2} \cdot 6 \mathrm{H}_{2} \mathrm{O}\right)$, chromium nitrate $\left(\mathrm{Cr}\left(\mathrm{NO}_{3}\right)_{3}\right.$ - $\left.9 \mathrm{H}_{2} \mathrm{O}\right)$ and iron nitrate $\left(\mathrm{Fe}\left(\mathrm{NO}_{3}\right)_{3} \cdot 9 \mathrm{H}_{2} \mathrm{O}\right)$ were used for synthesis. Citric acid $\left(\mathrm{C}_{6} \mathrm{H}_{8} \mathrm{O}_{7} \cdot \mathrm{H}_{2} \mathrm{O}\right)$ was used as fuel. The reaction procedure was carried out in an air atmosphere without the protection of inert gases. Metal nitrates and citric acid were used in the molar ratio 1:3. The metal nitrates were dissolved in desired stoichiometric proportions together in the minimum amount of double-distilled water to obtain a clear solution. An aqueous solution of citric acid was mixed with the metal-nitrate solution, and ammonia solution was slowly added to adjust the $\mathrm{pH} \approx 7$. The mixed solution was placed on a hot plate with continuous stirring at $90{ }^{\circ} \mathrm{C}$. During evaporation, a very viscous brown gel was formed. When all of the water molecules were removed from the mixture, the viscous gel began to froth. After few minutes, the gel was ignited and burnt with glowing flints. The decomposition reaction continued until the entire citrate complex was consumed. The auto-combustion was completed within a minute, yielding brown-colored ash as the precursor. Sintering temperature was determined from TGA / DTA and prepared powders of all the precursor samples were sintered at $500{ }^{\circ} \mathrm{C}$ for $4 \mathrm{~h}$ to obtain the final product.

\section{2. Characterization of Samples}

Simultaneous thermo gravimetric (TGA) and differential thermal analysis (DTA) of precursors were carried on SDT Q600 V20.9 Build 20 instrument in air atmosphere at heating rate $10{ }^{\circ} \mathrm{C} / \mathrm{min}$, within temperature range $25{ }^{\circ} \mathrm{C}$ to $800{ }^{\circ} \mathrm{C}$. The compositional stoichiometry was determined by energy dispersive X-ray spectroscopy (EDAX, Inca Oxford, attached to the SEM).The crystallographic structures were identified by X-ray powder diffraction with $\mathrm{Cu}-\mathrm{K}_{\alpha}$ radiation $(\lambda=1.5405 \AA)$ by Phillips $\mathrm{X}$-ray diffractometer (Model 3710). The infrared spectra of all the samples were recorded at room temperature in the range 300 to $800 \mathrm{~cm}^{-1}$ using Perkin Elmer infrared spectrophotometer. Morphology and structure of the powder samples were studied on JEOL-JSM-5600 N Scanning Electron Microscope (SEM) and on Philips (model CM 200) Transmission Electron Microscope (TEM).

\section{Results and Discussion}

\section{1. Thermal Analysis (TGA / DTA)}

The typical TGA/DTA curves of $\mathrm{Ni}_{0.2} \mathrm{Cu}_{0.2} \mathrm{Zn}_{0.6} \mathrm{Fe}_{2}$ ${ }_{\mathrm{x}} \mathrm{Cr}_{\mathrm{x}} \mathrm{O}_{4}(\mathrm{x}=0.0$; Figure 1 and $\mathrm{x}=1.0$; Figure 2), illustrates

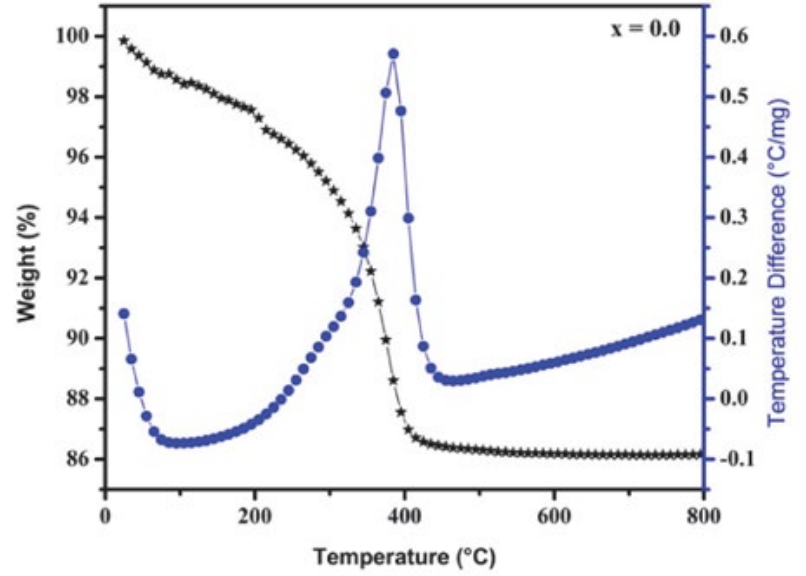

Figure 1: TGA-DTA plot for precursor of $\mathrm{Ni}_{0.2} \mathrm{Cu}_{0.2} \mathrm{Zn}_{0.6} \mathrm{Fe}_{2-\mathrm{x}} \mathrm{Cr}_{\mathrm{x}} \mathrm{O}_{4}$ $(\mathrm{x}=0.0)$

two weight loss steps. The first weight loss step in the temperature range of $30-100^{\circ} \mathrm{C}$, corresponding to endothermic peak around $80^{\circ} \mathrm{C}$, which is due to the loss of coordination water in the precursor. The second weight loss step observed in the temperature range of $310-425^{\circ} \mathrm{C}$ corresponding to the exothermic peak around $380^{\circ} \mathrm{C}$, is as a result of the decomposition of unreacted starting citric acid remained after combustion. The released heat in the process of exothermic decomposition has been observed to be sufficient for complete conversion of the metal precursors to metal oxides. ${ }^{26}$

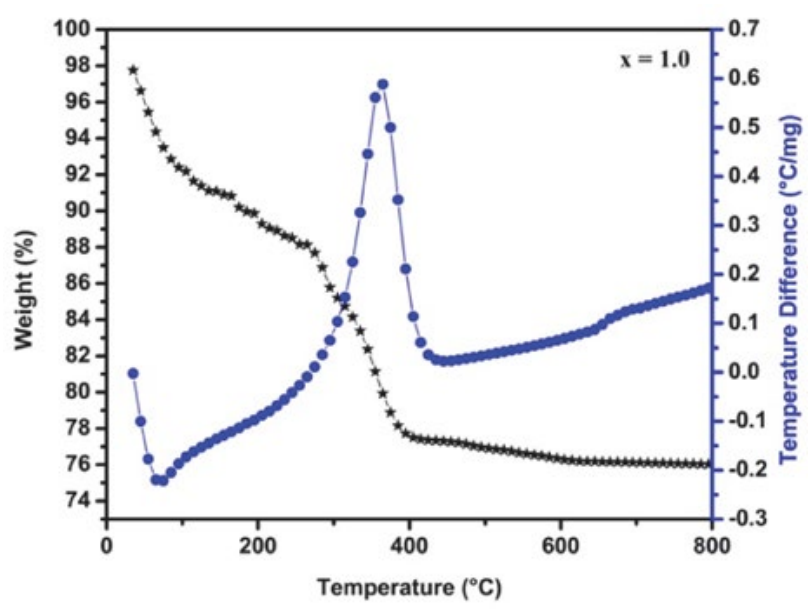

Figure 2. TGA-DTA plot for precursor of $\mathrm{Ni} 0.2 \mathrm{Cu} 0.2 \mathrm{Zn} 0.6 \mathrm{Fe} 2$ ${ }_{\mathrm{x}} \mathrm{Cr}_{\mathrm{x}} \mathrm{O}_{4}(\mathrm{x}=1.0)$

Almost no weight loss was observed above $425^{\circ} \mathrm{C}$, representing the presence of only $\mathrm{Ni}_{0.2} \mathrm{Cu}_{0.2} \mathrm{Zn}_{0.6} \mathrm{Fe}_{2-\mathrm{x}} \mathrm{Cr}_{\mathrm{x}} \mathrm{O}_{4}$ ferrites in this temperature range.

\section{2. Structural Analysis}

\section{2. 1. Elemental Analysis}

The compositional stoichiometry of $\mathrm{Ni}_{0.2} \mathrm{Cu}_{0.2} \mathrm{Zn}_{0.6} \mathrm{Fe}_{2 \text { - }}$ ${ }_{x} \mathrm{Cr}_{\mathrm{x}} \mathrm{O}_{4}$ ferrite nanoparticles was determined by EDAX. 


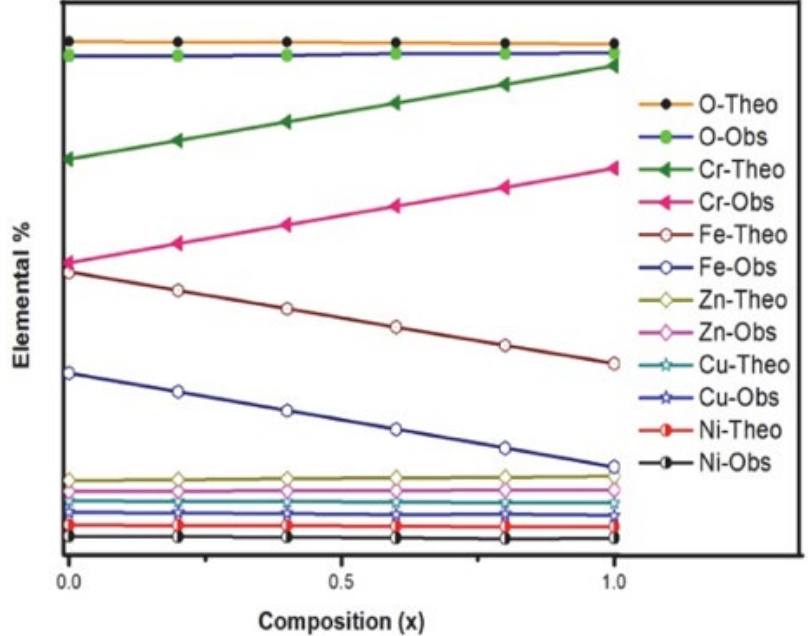

Figure 3. Plots of Observed and Theoretical elemental \% versus composition $(\mathrm{x})$

The EDAX confirmed the homogeneous mixing of the $\mathrm{Fe}, \mathrm{Ni}, \mathrm{Cu}, \mathrm{Zn}, \mathrm{Cr}$ and $\mathrm{O}$ atoms in pure and doped ferrite samples. Figure 3 shows the plots of observed and theoretical percentage of $\mathrm{Fe}, \mathrm{Ni}, \mathrm{Cu}, \mathrm{Zn}, \mathrm{Cr}$ and $\mathrm{O}$ values versus composions (x). The observed elemental \% (obtained from EDAX) values are in close agreement with theoretical \% (the starting composition used for the preparation) values. The EDAX analysis is affected by the surface crystalline defects of the nanoparticles. This can also be taken into account to explain the difference between the values of the atomic ratio as determined by EDAX and the expected value. ${ }^{27,28}$

\section{2. 2. X-ray Diffraction}

$\mathrm{X}$-ray diffraction (XRD) patterns of the $\mathrm{Ni}_{0}$ ${ }_{2} \mathrm{Cu}_{0.2} \mathrm{Zn}_{0.6} \mathrm{Fe}_{2-\mathrm{x}} \mathrm{Cr}_{\mathrm{x}} \mathrm{O}_{4}(\mathrm{x}=0.0,0.2,0.4,0.6,0.8$ and 1.0 ) spinel ferrite system are shown in Figure 4. The XRD patterns confirmed the formation of single phase cubic spinel structure without additional peaks corresponding to any other phases. The crystal structures of $\mathrm{Ni}-\mathrm{Cu}-\mathrm{Zn}$ ferrite are identified as cubic spinel (space group: $\mathrm{fd}^{3} \mathrm{~m}$ ) with the corresponding (220), (311), (222), (400), (422), (333) and (440) planes.

Lattice parameter (a) of all the samples was determined by using the following equation: ${ }^{29}$

$$
\mathrm{a}=\mathrm{d} \sqrt{\mathrm{h}^{2}+\mathrm{k}^{2}+\mathrm{l}^{2}}
$$

Lattice constant (a) values with an accuracy of \pm $0.002 \AA$ Á were calculated for each sample using XRD pattern and are listed in Table 1. It is observed that the lattice constant (a) decreases with increase in $\mathrm{Cr}^{3+}$ concentration. In the present ferrite system $\mathrm{Fe}^{3+}$ ions $(0.67 \AA \hat{)})$ ions are replaced by the relatively small $\mathrm{Cr}^{3+}$ ions $(0.64 \AA$ ) $)$. The decrease in the lattice constant is related to the difference in ionic radii of $\mathrm{Fe}^{3+}$ and $\mathrm{Cr}^{3+} \cdot{ }^{30-32}$

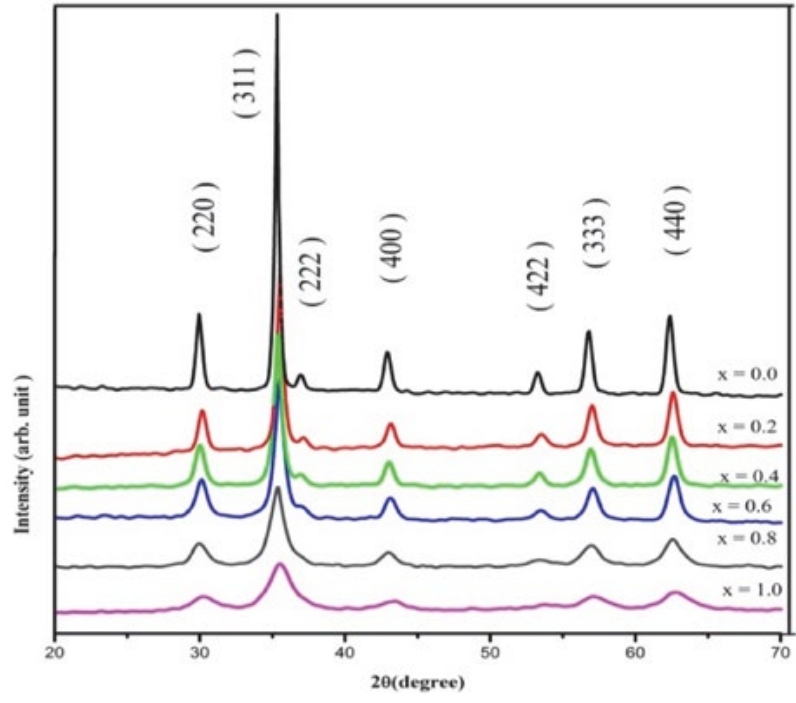

Figure 4. The XRD patterns for $\mathrm{Ni}_{0.2} \mathrm{Cu}_{0.2} \mathrm{Zn}_{0.6} \mathrm{Fe}_{2-\mathrm{x}} \mathrm{Cr}_{\mathrm{x}} \mathrm{O}_{4}$

The X-ray density of all the samples was obtained by the following relation:

$$
\mathrm{d}_{\mathrm{x}}=\frac{8 \mathrm{M}}{\mathrm{Na}^{3}}
$$

Where, ' 8 ' is formula unit, ' $\mathrm{M}$ ' is molecular weight, ' $N$ ' is Avogadro's number, ' $a$ ' is lattice constant. The values of X-ray density are presented in table 1 . It is seen from Table1 that, like lattice parameter, X-ray density also decreased with increasing $\mathrm{Cr}^{3+}$ content ' $\mathrm{x}$ '. The decrease in X-ray density is attributed to decrease in lattice constant. It is observed that X-ray density increase for $\mathrm{X}=1.0$. This is related to the molecular weight of the sample overtakes the volume $\left(\mathrm{a}^{3}\right)$.

The average crystallite diameter ' $\mathrm{D}_{\mathrm{XRD}}$ ' of powder estimated from the most intense (311) peak of XRD and using the Debye-Scherrer method, ${ }^{29}$

$$
D_{X R D}=\frac{C \lambda}{\beta_{1 / 2} \cos \theta}
$$

Where, $\beta_{1 / 2}$ is the full width of half maximum in

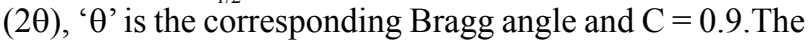
values of the crystallite size are given in Table 1 . The crystallite size is decreases from $30.3 \mathrm{~nm}$ to $8.9 \mathrm{~nm}$ with increasing $\mathrm{Cr}^{3+}$ substitution. The decrease in the crystallite size indicates that the addition of the $\mathrm{Cr}^{3+}$ obstruct the crystal growth. ${ }^{33}$ Due to the surface temperature and the molecular concentration at the surface of the crystal results into decrease in the crystal growth.

The percentage porosity ' $\mathrm{P}$ ' of all the samples was calculated using the values of $X$-ray density and bulk density:

$$
P=1-\frac{d_{B}}{d_{x}} \times 100
$$


Table 1. Lattice constant (a), X-ray density $\left(\mathrm{d}_{\mathrm{x}}\right)$ and hopping lengths $\left(\mathrm{L}_{\mathrm{A}}\right)$ and $\left(\mathrm{L}_{\mathrm{B}}\right)$, particle size $\left(\mathrm{D}_{\mathrm{xrd}}\right)$ and porosity $(\mathrm{P})$ of $\mathrm{Ni}_{0.2} \mathrm{Cu}_{0.2} \mathrm{Zn}_{0.6} \mathrm{Fe}_{2-\mathrm{x}} \mathrm{Cr}_{\mathrm{x}} \mathrm{O}_{4}$

\begin{tabular}{|c|c|c|c|c|c|c|c|}
\hline \multirow{2}{*}{$\begin{array}{c}\text { Composition } \\
\text { ' } \mathrm{x} \text { ' }\end{array}$} & \multirow{2}{*}{$\begin{array}{l}\text { 'a' } \\
(\AA ̊)\end{array}$} & \multirow{2}{*}{$\begin{array}{c}\mathbf{d}_{x}^{\prime} \\
\left(\mathrm{g} / \mathrm{cm}^{3}\right)\end{array}$} & \multirow{2}{*}{$\begin{array}{c}\mathbf{L}_{\mathrm{A}} \\
(\AA)\end{array}$} & \multirow{2}{*}{$\begin{array}{c}\mathbf{L}_{\mathrm{B}} \\
(\AA)\end{array}$} & \multirow{2}{*}{$\begin{array}{c}\mathbf{P} \\
(\%)\end{array}$} & \multicolumn{2}{|c|}{ Particle size (nm) } \\
\hline & & & & & & $\mathrm{D}_{\mathrm{xrd}}$ & TEM \\
\hline 0.0 & 8.418 & 5.329 & 3.645 & 2.976 & 25.4 & 30.3 & 30.6 \\
\hline 0.2 & 8.415 & 5.316 & 3.644 & 2.975 & 26.1 & 24.9 & 25.2 \\
\hline 0.4 & 8.406 & 5.317 & 3.640 & 2.972 & 27.7 & 19.1 & 19.5 \\
\hline 0.6 & 8.394 & 5.323 & 3.634 & 2.967 & 28.7 & 16.4 & 15.9 \\
\hline 0.8 & 8.389 & 5.314 & 3.632 & 2.966 & 28.4 & 12.6 & 12.8 \\
\hline 1.0 & 8.367 & 5.339 & 3.623 & 2.958 & 32.0 & 8.9 & 9.5 \\
\hline
\end{tabular}

Where, $d_{B}$ and $d_{x}$ are the bulk and X-ray densities respectively.

It is observed that porosity increased from $25.4 \%(\mathrm{x}$ $=0.0)$ to $32 \%(\mathrm{x}=1.0)$ with the $\mathrm{Cr}^{3+}$ substitution. In the present series of $\mathrm{Ni}_{0.2} \mathrm{Cu}_{0.2} \mathrm{Zn}_{0.6} \mathrm{Fe}_{2-\mathrm{x}} \mathrm{Cr}_{\mathrm{x}} \mathrm{O}_{4}$, both the molecular weight and the volume of the unit cell decrease with increasing $\mathrm{Cr}^{3+}$ substitution, but the rate of the decrease of molecular weight is more than that of volume. Therefore, the density decreases with $\mathrm{Cr}^{3+}$ substitution, this resulted in increase in porosity. Apart from this, the increase in porosity is mainly attributed to decrease in crystallite size, which increases the grain boundaries of the particle and accordingly the porosity. ${ }^{27}$

The distance between the magnetic ions i.e. hopping lengths $\left(\mathrm{L}_{\mathrm{A}}\right.$ and $\left.\mathrm{L}_{\mathrm{B}}\right)$ in the tetrahedral $\mathrm{A}$-site and octahedral $\mathrm{B}-$ site was calculated using following relation: ${ }^{34}$

$$
\begin{aligned}
L_{A} & =\frac{a \sqrt{3}}{4} \\
L_{B} & =\frac{a \sqrt{2}}{4}
\end{aligned}
$$

It has been observed from Table 1 that the hopping lengths $\left(\mathrm{L}_{\mathrm{A}}\right.$ and $\left.\mathrm{L}_{\mathrm{B}}\right)$ decreased with $\mathrm{Cr}^{3+}$ substitution. Decrease in both the hopping lengths with $\mathrm{Cr}^{3+}$ substitution is due to the decrease in lattice constant.

\section{2. 3. Infrared Spectroscopy}

The infrared spectroscopy is an important tool to probe various ordering phenomena that provide information on the position of ions and vibrational modes of crystals. The substitution of metal ion in ferrites may give rise to structural change within the unit cell without affecting the structure as a whole. Such structural changes brought about by metal ions strongly influence the lattice vibrations. ${ }^{35}$ The IR spectra as shown in Figure 5, were recorded at room temperature in the frequency range 300-800 $\mathrm{cm}^{-1}$. For ferrites, generally it is found two assigned absorption bands appear around $600 \mathrm{~cm}^{-1}: v_{1}$, which is attributed to stretching vibration of tetrahedral groups $\mathrm{Fe}^{3+}-\mathrm{O}^{2-}$ and around $400 \mathrm{~cm}^{-1}: v_{2}$, which is attributed to the octahedral groups complex $\mathrm{Fe}^{3+}-\mathrm{O}^{2-}$. It is observed from Table 2 and Figure 6 that the higher frequency band $\left(v_{1}\right)$ is appeared in the range of $568-610 \mathrm{~cm}^{-1}$ whereas lower frequency band $\left(v_{2}\right)$ is appeared in the range of $388-491 \mathrm{~cm}^{-1}$. These bands are characteristics features of spinel structure. It explains that the normal mode of vibration of tetrahedral cluster is higher than that of octahedral cluster. It should be attributed to the shorter bond length of tetrahedral cluster and longer bond length of octahedral cluster. ${ }^{35}$

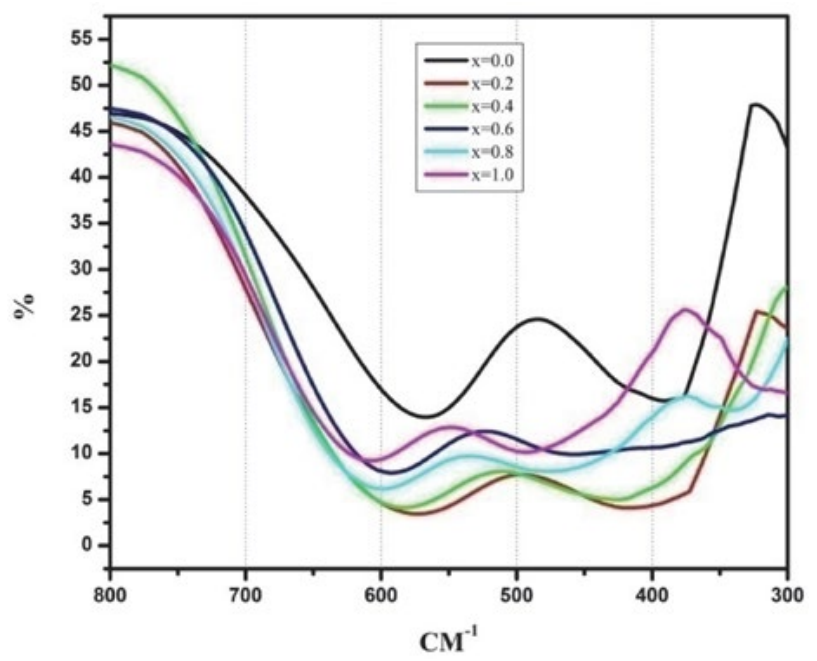

Figure 5. IR spectra for the series $\mathrm{Ni}_{0.2} \mathrm{Cu}_{0.2} \mathrm{Zn}_{0.6} \mathrm{Fe}_{2-\mathrm{x}} \mathrm{Cr}_{\mathrm{x}} \mathrm{O}_{4}$

The differences in band position and intensity with $\mathrm{Cr}^{3+}$ substitution may be related to; the decrease in the $\mathrm{Fe}_{B}^{3+}$ $-\mathrm{O}_{2}^{2-}$ intermolecular distance increases the metal-oxygen vibrational energies, which arises from the decrease in the number of $\mathrm{Fe}^{3+}-\mathrm{O}_{2}^{2-}$ complexes caused by the increase of the number of $\mathrm{Cr}^{2+}-\mathrm{O}_{2}^{2-}$ complexes ${ }^{35}$ and, formation of $\mathrm{Me}^{2+}-\mathrm{O}_{2}^{2-}$ at $\mathrm{A}$ and $\mathrm{B}$ sites $\left(\mathrm{Me}=\mathrm{Ni}^{2+}, \mathrm{Cu}^{2+}, \mathrm{Zn}^{2+}\right)$.

The force constants corresponding to the tetrahedral and octahedral complexes are calculated by using the standard formulae given below: ${ }^{36}$

$$
\begin{aligned}
& K_{t}=7.62 \times M_{1} \times v_{1}^{2} \times 10^{-2} \\
& K_{o}=10.62 \times \frac{M_{2}}{2} \times v_{2}^{2} \times 10^{-2}
\end{aligned}
$$


Table 2. Band position $\left(v_{1}\right.$ and $\left.v_{2}\right)$, Force constant $\left(\mathrm{K}_{0}\right.$ and $\left.\mathrm{K}_{\mathrm{t}}\right)$ and Bond length $\left(\mathrm{R}_{\mathrm{A}}\right.$ and $\left.\mathrm{R}_{\mathrm{B}}\right)$ of system $\mathrm{Ni}_{0.2} \mathrm{Cu}_{0.2} \mathrm{Zn}_{0.6} \mathrm{Fe}_{2-\mathrm{x}} \mathrm{Cr}_{\mathrm{x}} \mathrm{O}_{4}$

\begin{tabular}{|c|c|c|c|c|c|c|}
\hline \multirow{2}{*}{$\begin{array}{l}\text { Comp. } \\
\text { ' } \mathrm{x} \text { ' }\end{array}$} & \multicolumn{2}{|c|}{ Band positions } & \multicolumn{2}{|c|}{ Force constants } & \multicolumn{2}{|c|}{ Bond lengths } \\
\hline & $v_{1}\left(\mathbf{c m}^{-1}\right)$ & $v_{2}\left(\mathbf{c m}^{-1}\right)$ & $\begin{array}{c}\mathrm{K}_{\mathrm{o}} \times 10^{5} \\
(\text { dyne } / \mathrm{cm})\end{array}$ & $\begin{array}{c}\mathrm{K}_{\mathrm{t}} \times 10^{5} \\
(\text { dyne } / \mathrm{cm})\end{array}$ & $\mathbf{R}_{\mathrm{A}}(\AA)$ & $\mathbf{R}_{\mathrm{B}}(\AA)$ \\
\hline 0.0 & 568.1 & 388.9 & 0.9380 & 1.6075 & 3.864 & 3.065 \\
\hline 0.2 & 574.6 & 418.1 & 1.0834 & 1.8388 & 3.862 & 3.064 \\
\hline 0.4 & 585.8 & 424.7 & 1.1182 & 1.8978 & 3.861 & 3.063 \\
\hline 0.6 & 597.2 & 447.2 & 1.2399 & 2.0884 & 3.859 & 3.063 \\
\hline 0.8 & 603.9 & 474.2 & 1.3937 & 2.3203 & 3.857 & 3.062 \\
\hline 1.0 & 610.5 & 491.9 & 1.4999 & 2.4789 & 3.855 & 3.061 \\
\hline
\end{tabular}

Where, $\mathrm{K}_{\mathrm{O}}$ is the force constant of octahedral site, $\mathrm{K}_{\mathrm{t}}$ is the force constant of tetrahedral site, $\mathrm{M}_{1}$ molecular weight of tetrahedral site, $M_{2}$ molecular weight of octahedral site, $v_{1}$ the corresponding center frequency on tetrahedral site, and $v_{2}$ the corresponding center frequency on octahedral site.

The molecular weights $M_{1}$ and $M_{2}$ for each sample are calculated from the cation distribution. The force constant is the second derivative of the potential energy with respect to the site radius with the other independent parameters kept constant. The bond lengths $R_{A}$ and $R_{B}$ have been calculated using the formula given by Gorter. ${ }^{37}$ The molecular weights of the tetrahedral $\mathrm{M}_{1}$ and octahedral $\mathrm{M}_{2}$ sites have been calculated using the cation. The values of $\mathrm{R}_{\mathrm{A}}, \mathrm{R}_{\mathrm{B}}$ and the force constants $\mathrm{K}_{\mathrm{t}}$ and $\mathrm{K}_{\mathrm{O}}$ are listed in Table: 2 .

\section{2. 4. Scanning Electron Microscopy (SEM)}

Typical Scanning electron micrograph (SEM) of the sample $\mathrm{x}=0.6$ is shown in Figure 6. Each composition is characterized by a typical porous structure and small rounded grains. It is observed from SEM images that the structure is affected by the $\mathrm{Cr}^{3+}$ substitutions. It can be observed from the SEM images that the prepared samples

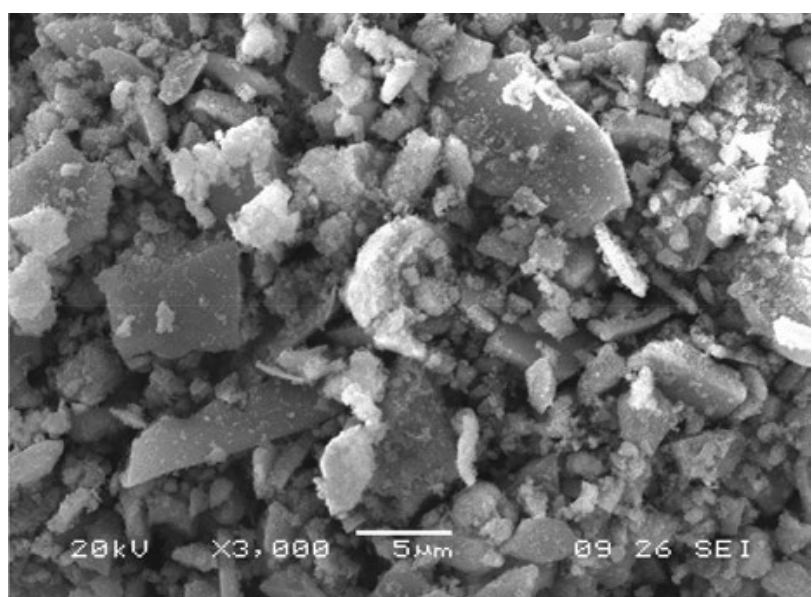

Figure 6. Scanning electron micrograph of $\mathrm{Ni}_{0.2} \mathrm{Cu}_{0.2} \mathrm{Zn}_{0.6} \mathrm{Fe}_{2-\mathrm{x}} \mathrm{Cr}_{\mathrm{x}} \mathrm{O}_{4}$ $(\mathrm{x}=0.6)$ are amorphous and porous in nature. The decrease in the grain size and an increase in porosity are observed with increasing $\mathrm{Cr}^{3+}$ substitutions. The observed changes in grain size suggest that the substitution of $\mathrm{Cr}^{3+}$ in $\mathrm{Ni}-\mathrm{Cu}-\mathrm{Zn}$ ferrite solid solution occurs during sol-gel combustion process which enables a better homogeneity in the powders and, hence, a more controlled microstructure is obtained.

\section{3. 5. Transmission Electron Microscopy (TEM)}

TEM image of the typical sample $\mathrm{x}=0.4$ is presented in Figure 7.

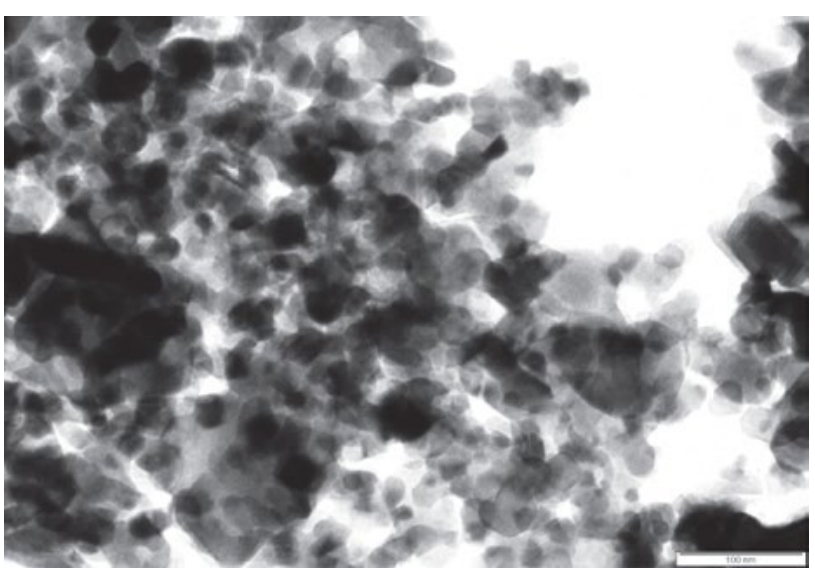

Figure 7. TEM image for $\mathrm{Ni}_{0.2} \mathrm{Cu}_{0.2} \mathrm{Zn}_{0.6} \mathrm{Fe}_{2-\mathrm{x}} \mathrm{Cr}_{\mathrm{x}} \mathrm{O}_{4}(\mathrm{x}=0.4)$

The particles were well distributed and slightly agglomerated. The agglomeration is the indication of high reactivity of the prepared sample with the heat treatment and it may also be come from the magnetostatic interaction between particles. Since $\mathrm{Cr}^{3+}$ ions provide stability to the $\mathrm{Ni}-\mathrm{Cu}-\mathrm{Zn}$ lattice; it is believed that they also inhibit the process of grain growth through coagulation at the stage where the sol-gel is formed and hence samples of small particle size are produced. ${ }^{38}$ Selected area electron diffraction (SAED) patterns of the respective TEM image is also shown in Figure 8. 


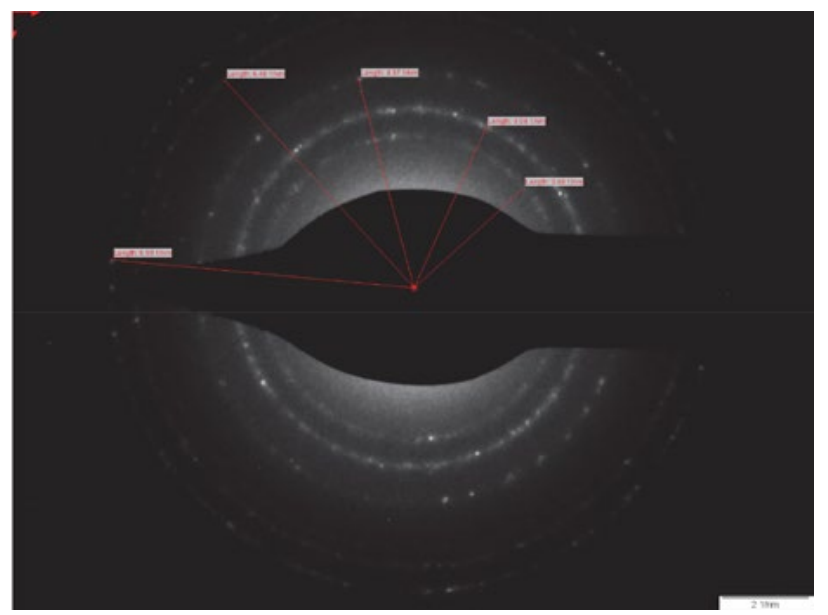

Figure 8. $\mathrm{SAED}$ pattern for $\mathrm{Ni}_{0.2} \mathrm{Cu}_{0.2} \mathrm{Zn}_{0.6} \mathrm{Fe}_{2-\mathrm{x}} \mathrm{Cr}_{\mathrm{x}} \mathrm{O}_{4}(\mathrm{x}=0.4)$

The Bragg' rings observed in these SAED patterns corresponding to specific ' $d$ ' values, that match perfectly with the ' $d$ ' values calculated from XRD. The superimposition of the bright spot with Debye ring pattern indicates polycrystalline nature of the sample which is in accordance with XRD. Like XRD; SAED also confirmed that the sample does not possess any type of impurity or second phase.

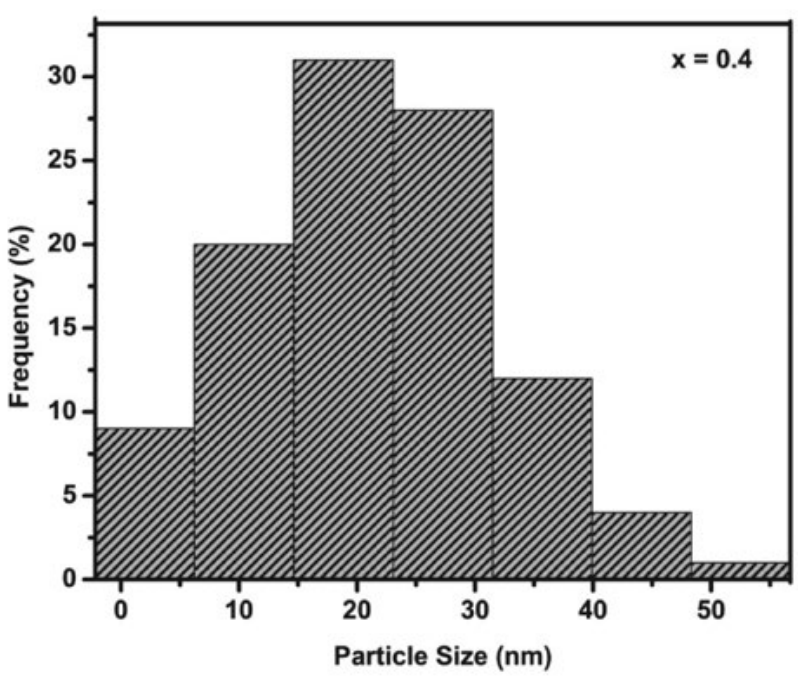

Figure 9. Particles size distribution for $\mathrm{Ni}_{0.2} \mathrm{Cu}_{0.2} \mathrm{Zn}_{0.6} \mathrm{Fe}_{2-\mathrm{x}} \mathrm{Cr}_{\mathrm{x}} \mathrm{O}_{4}(\mathrm{x}=$ 0.4 ) (based on TEM micrograph, Figure 7)

Particles size distributions for $\mathrm{Ni}_{0.2} \mathrm{Cu}_{0.2} \mathrm{Zn}_{0.6} \mathrm{Fe}_{2}$ ${ }_{x} \mathrm{Cr}_{\mathrm{x}} \mathrm{O}_{4}(\mathrm{x}=0.4)$ shown in figure 9. Nanocrystalline particles observed were in the range 6-55 nm. Particles with size between 10-30 nm were most abundant (more than $70 \%$ ). The samples particle size obtained from TEM are in close agreement to the size calculated from the Debye-Scherrer method.

\section{Conclusion}

Nanocrystalline $\mathrm{Ni}_{0.2} \mathrm{Cu}_{0,2} \mathrm{Zn}_{0.6} \mathrm{Fe}_{2-\mathrm{x}} \mathrm{Cr}_{\mathrm{x}} \mathrm{O}_{4}$ ferrites with $\mathrm{x}=0.0,0.2,0.4,0.6,0.8$, and 1.0 were prepared by sol gel auto combustion method using citric acid as a fuel. The EDAX pattern confirmed the homogeneous mixing in pure and doped ferrite samples with desired composition. Structural analysis with XRD reveals that the system confirms the formation of single phase cubic spinel structure of Chromium doped Ni-Cu-Zn Nano Ferrites. Lattice constant and X-ray density decreased with $\mathrm{Cr}^{3+}$ substitution. The crystallite size is observed in the range of 8.9-30.3 $\mathrm{nm}$, which is in close agreement with crystallite size obtained from TEM. It is concluded from IR spectra that higher frequency band $\left(v_{1}\right)$ is appeared in the range of $568-610 \mathrm{~cm}^{-1}$ whereas lower frequency band $\left(v_{2}\right)$ is appeared in the range of $388-491 \mathrm{~cm}^{-1}$ confirming characteristics features of spinel structure. It is observed from SEM that the prepared samples are amorphous and porous in nature. TEM images of the samples confirmed the particle size of obtained ferrite samples is in $\mathrm{nm}$ dimensions. The prepared Chromium doped Ni-Cu-Zn Nano Ferrites may be used as catalyst for organic transformations and in several devices such as antennas, memory storage devices, microwave devices etc.

\section{References}

1. Mathew, T., Shylesh, S., Devassy, B. M., Vijayaraj, et al., Applied Catalysis A: General, 2004, 273(1), 35-45.

DOI:10.1016/j.apcata.2004.06.011

2. Lu, H. C., Chang, J. E., Vong, W. W., Chen, et al., International Journal of Physical Sciences, 2011, 6(4), 855-865.

3. Lim, C. W., Lee, I. S., Nano Today, 2010, 5(5), 412-434. DOI:10.1016/j.nantod.2010.08.008

4. Kooti, M., Afshari, M., Scientia Iranica, 2012, 19(6), 19911995. DOI:10.1016/j.scient.2012.05.005

5. H. Su, H. Zhang, X. Tang, Z. Zhong, Y. Jing, Mater. Sci. Eng. B, 2009, 162, 22-25. DOI:10.1016/j.mseb.2009.01.030

6. Wang, Sea-Fue, et al., Journal of Magnetism and Magnetic Materials, 2015, 394, 470-476.

DOI:10.1016/j.jmmm.2015.07.037

7. Ahmadpour Ghader, Ali Ghasemi, Ebrahim Paimozd, Current Nanoscience, 2012, 8.4, 598-602.

DOI: $10.2174 / 157341312801784393$

8. T. Nakamura, J. Magn. Magn. Mater., 1997, 168, 285-291. DOI:10.1016/S0304-8853(96)00709-3

9. R. Lebourgeois, S. Duguey, J. P. Ganne, J. M. Heintz, J. Magn. Magn. Mater., 2007, 312, 328-330.

DOI:10.1016/j.jmmm.2006.10.698

10. J. H. Jean, C. H. Lee, W. S. Kou, J. Am. Ceram. Soc., 1999, 82, 343. DOI:10.1111/j.1551-2916.1999.tb20068.x

11. V. V. Awati, S. M. Rathod, Sagar E. Shirsath, Maheshkumar L. Mane, J. Alloys Compds, 2013, 553, 157-162.

DOI:10.1016/j.jallcom.2012.11.045 
12. T. Krishnaveni, B. Rajini Kanth, V. Seetha Rama Raju, S.R. Murthy, J. Alloys Compds, 2006, 414, 282-286. DOI:10.1016/j.jallcom.2005.07.029

13. T. Krishnaveni, B. Rajini Kanth, et al., Journal of Alloys and Compounds, 2006, 414, 282-286.

DOI:10.1016/j.jallcom.2005.07.029

14. Yen-Pei Fu, Ko-Yin Pan, Cheng-Hsiung Lin, Materials Letters, 2002, 57, 291-296.

DOI:10.1016/S0167-577X(02)00780-2

15. Li, Bo, et al., Materials Science and Engineering: B, 2003, 99. 1, 252-254. DOI:10.1016/S0921-5107(02)00489-0

16. Zhu, Haikui, et al., Ceramics International, 2014, 40.7, 1098510989. DOI:10.1016/j.ceramint.2014.03.102

17. M. A. Gabal, Y. M. Al Angari, A. Y. Obaid, Advanced Powder Technology, 2014, 25, 457-461.

DOI:10.1016/j.apt.2013.07.009

18. M. Epifani, E. Melissano, G. Pace, M. Schiopa, J. Europ. Ceram. Soc., 2007, 27, 115-123.

DOI:10.1016/j.jeurceramsoc.2006.04.084

19. N. L. Freitas, J. P. Continho, M. C. Silva, H. L. Lira, et al., Materials Science Forum, 2010, 660, 943-947.

DOI:10.4028/www.scientific.net/MSF.660-661.943

20. Tiago Pinheiro Braga, Bárbara Maria Campos Sales, et al., Catal. Sci. Technol., 2011, 1, 1383-1392.

DOI:10.1039/c1cy00176k

21. Y. Ahn, E. J. Choi, S. Kim, H. N. Ok, Mater. Lett., 2001, 50 (1), 47-52. DOI:10.1016/S0167-577X(00)00412-2

22. Lohar K. S., Pachpinde A. M., Langade M. M., et al., Journal of Alloys and Compounds, 2014, 604, 204-210.

DOI:10.1016/j.jallcom.2014.03.141

23. B. G. Toksha, Sagar E. Shirsath, M. L. Mane, S. M. Patange, S. S. Jadhav, K. M. Jadhav, J. Phys. Chem. C, 2011, 115, 2090520912 DOI:10.1021/jp205572m
24. Sagrario M. Montemayor, L. A. Garcia-Cerda, J. R. Torres-Lubian, O. S. Rodriguez-Fernandez, J Sol-Gel Sci Techn, 2007, $42,181-186$

25. J. Azadmanjiri, Mater. Chem. Phys., 2008, 109, 109-112

DOI:10.1016/j.matchemphys.2007.11.001

26. A. Mali, A. Ataie, Ceramics International, 2004, 30, 19791983. DOI:10.1016/j.ceramint.2003.12.178

27. Hashim, Mohd, et al., Powder technology, 2012, 229, 37-44. DOI:10.1016/j.powtec.2012.05.054

28. K. S. Lohar, S. M. Patange, S. E. Shirsath et al., Int. J. of Modern Phy. B, 2011, 25-16, 2157-2166.

29. B. D. Cullity, "Elements of X-ray diffraction", (Addison-Wesley Publ. Comp. Inc., Reading, Massachusetts, U.S.A.), 1956, pp. 99.

30. S. M. Patange, Sagar E Shirsath, et al., Appl. Phys. A: Mater Sci. Proces, 2009, A95, 429-434.

DOI:10.1007/s00339-008-4897-0

31. N. Kumari, V. Kumar, K. Singh, J. Alloys Compd., 2015, 622, 628-634. DOI:10.1016/j.jallcom.2014.10.083

32. Yuksel Koseoglu, Ceramics international, 2015, 41, 64176423. DOI:10.1016/j.ceramint.2015.01.079

33. M. Ashtara, A. Munirb, M. Anis-ur-Rehmanb, A. Maqsooda, Materials Research Bulletin, 2016, 79, 14-21.

34. B. Vishwanathan and V. R. K. Murthy, Ferrite Material Science and Technology, New Delhi: Narsoa Publishing House, 1990, pp. 15-61.

35. S. S. Bellad, R. B. Pujar, B. K. Chougule, Indian J. Pure Appl. Phys., 1998, 36, 598-601.

36. A. A. Yousef, M. E. El-Zain, S. A. Mazen, et al., J. Phys. Condens. Matter, 1994, 6(29), 5717-5724.

DOI:10.1088/0953-8984/6/29/014

37. E. W. Gorter, Philips Res. Rep., 1954, 9, 295-320.

38. Muhammad Javed Iqbal, Barkat-ul-Ain, Mater. Sci. Engg. B, 2009, 164, 6-11.

\section{Povzetek}

Nanoferite Ni-Cu-Zn dopirane s kromom in s kemijsko sestavo $\mathrm{Ni}_{0.2} \mathrm{Cu}_{0.2} \mathrm{Zn}_{0.6} \mathrm{Fe}_{2-\mathrm{x}} \mathrm{Cr}_{\mathrm{x}} \mathrm{O}_{4}(\mathrm{x}=0.0,0.2,0.4,0.6,0.8,1.0)$ smo pripravili z modificirano sol-gel metodo. Tako pripravljene s kromom substituirane prekurzurje Ni-Cu-Zn feritov smo sintrali štiri ure pri $500{ }^{\circ} \mathrm{C}$. Kemijsko sestavo smo potrdili z energijsko disperzivno rentgensko analizo (EDAX). Podatki rentgenske praškovne analize (XRD) pa razkrivajo, da so imajo vsi vzorci le eno fazo in kubično spinelno strukturo. Konstante osnovne celice, razdalje med magnetnimi ioni in velikost kristalitov, ki smo jih določili z rentgensko praškovno analizo se zmanjšujejo $\mathrm{z}$ večanjem koncentracije $\mathrm{Cr}^{3+}$ ionov. $\mathrm{V}$ infrardečih spektrih prevladujeta dva trakova: trak pri visokih frekvencah $v_{1} \approx 600 \mathrm{~cm}^{-1}$ in nizkih frekvencah $v_{2} \approx 450 \mathrm{~cm}^{-1}$, ki ju lahko pripišemo valenčnim nihanjem $\mathrm{v}$ tetraedričnih in oktaedričnih okoljih. Morfologijo površine pripravljenih vzorcev smo preučevali z uporabo vrstične elektronske mikroskopije (SEM) in presevne elektronske mikroskopije (TEM). 